\title{
Epigenetic modifications may play a role in the developmental consequences of early life events
}

\author{
Frank H. Bloomfield
}

Received: 17 May 2011 /Accepted: 27 September 2011 / Published online: 8 October 2011

(C) Springer Science+Business Media, LLC 2011

\begin{abstract}
Many aspects of postnatal development are influenced by events before birth, including cognitive and language development. An adverse intrauterine environment, for example secondary to poor maternal nutritional status, multiple pregnancy, or late preterm birth, is associated with increased risks of delayed or impaired childhood development and altered physiology in adulthood that may predispose to increased risk of adult disease. Maternal periconceptional undernutrition and twin conception can both result in late preterm birth, but it is less clear whether cases of late preterm birth not following a recognized early pregnancy event may still have their origin in the periconceptional period. Thus, the very earliest periods of pregnancy, and perhaps even the prepregnancy period, may be an important period determining the developmental trajectory of the fetus, and thus both pregnancy and later health outcomes. Profound epigenetic modifications to the genome occur in the early embryo as a normal part of development. Recent evidence suggests that environmental signals acting during early development may also result in epigenetic changes which may play a role in mediating the association between early life exposures and later phenotype.
\end{abstract}

\footnotetext{
F. H. Bloomfield $(\bowtie)$

Liggins Institute, University of Auckland,

Private Bag 92019,

Auckland 1142, New Zealand

e-mail: f.bloomfield@auckland.ac.nz

F. H. Bloomfield

National Research Centre for Growth and Development,

Auckland, New Zealand
}

Keywords Maternal nutrition - Twin conception · Late preterm birth - Developmental origins of health and disease $\cdot$ Epigenetics

\section{Introduction}

The association between reduced size at birth, reflecting an adverse intrauterine environment, and increased risk of common adult diseases such as type 2 diabetes and cardiovascular disease is now well established (Harding et al. 2010; McMillen and Robinson 2005). More recent data suggest that sensory and cognitive outcomes may also be linked to early life events (Raikkonen and Pesonen 2009). However, although reduced size at birth and altered postnatal growth trajectories are markers for later risk of both metabolic (Nobili et al. 2008) and cognitive outcomes (Heinonen et al. 2010; Heinonen et al. 2008), birthweight is a poor proxy for altered prenatal development secondary to an intrauterine exposure to an adverse environment (Gillman 2002). Rather, evidence is accumulating that events in the very earliest stages of pregnancy may determine developmental trajectory of the fetus, not only for outcomes such as birthweight and gestation length (Bloomfield 2011; Muhlhausler et al. 2011), but also for individual organ systems. Early embryonic development is characterized by genome wide epigenetic reprogramming between the zygote and morula stages, involving both a loss of DNA methylation and histone modifications (Feng et al. 2010). This epigenetic reprogramming may be transmitted through the germ line (Reik and Walter 2001; Reik 2007) but also can be influenced by environmental 
signals such as nutrients (Waterland and Jirtle 2004; Burdge and Lillycrop 2010) and hormones (Fowden and Forhead 2009). Epigenetic modifications may, therefore, be an important mechanism by which early environmental signals affect postnatal development.

\section{Maternal nutrition, glucocorticoids, and fetal development}

Both maternal undernutrition and maternal obesity are associated with altered fetal development and increased risk of disease in the offspring (Poston et al. 2011; Langley-Evans and McMullen 2010). Based to a large extent on studies in rodents (Lesage et al. 2001), which have a short gestation length, it has been proposed that the effects of maternal undernutrition on fetal development are mediated via exposure of the fetus to increased circulating concentrations of maternal glucocorticoids (Seckl and Meaney 2004).

The critical role that glucocorticoids play in fetal development is well demonstrated by the importance of the preparturient fetal cortisol surge in preparing the fetus for extrauterine life (Liggins 1994), which has been described in all species studied to date. The fetus is usually protected from excess maternal glucocorticoids by enzyme activity in the placenta (see below), but the fact that synthetic glucocorticoids are not substrates for this enzyme has been exploited clinically in women at risk of preterm birth. In this setting, administration of synthetic glucocorticoids to the mother results in maturation of the fetal lungs, gastrointestinal tract, and subependymal capillary networks resulting in approximately a halving of the risks of mortality, necrotising enterocolitis, and intraventricular hemorrhage following preterm birth (Roberts and Dalziel 2006).

Maternal undernutrition is proposed as one circumstance in which fetuses may be exposed to inappropriate levels of maternal glucocorticoids resulting in altered development with consequences in postnatal life (Seckl and Meaney 2004; Fowden et al. 1998). For example, babies with reduced size at birth or whose mothers were exposed to an unbalanced diet during pregnancy have altered functioning of the hypothalamic-pituitary-adrenal axis (HPAA) in childhood and adulthood (Jones et al. 2006; Phillips et al. 2000; Reynolds et al. 2007). However, other studies in humans have found a U-shaped association between size at birth and postnatal HPAA function assessed by cortisol responses to psychosocial stress (the Trier social stress test) (Kajantie et al. 2007), and in adults who were born to women exposed to famine during the Dutch Hunger winter there was no association between maternal exposure to famine and offspring cortisol response to a Trier social stress test. The rationale behind the hypothesis that glucocorticoids may mediate the effects of undernutrition stem from elegant experiments in rats demonstrating that undernutrition increases maternal circulating glucocorticoid concentrations and decreases mRNA expression and activity of the placental enzyme $11 \beta$-hydroxysteroid dehydrogenase (11 $\beta$-HSD) type 2 , which acts as a placental barrier protecting the fetus from maternal circulating glucocorticoids by inactivating active cortisol to inactive cortisone (corticosterone to dehydrocorticosterone in the rat) (Lesage et al. 2001; Blondeau et al. 2001). Furthermore, inhibition of total (both type 1 and 2) $11 \beta$-HSD activity in rats with carbenoxolone results in decreased birthweight and higher offspring blood pressure (Langley-Evans 1997). Dietary protein restriction in pregnant rat dams has been shown to result in increased expression of the glucocorticoid receptor (GR) and peroxisome proliferator-activated receptor- $\alpha$ in the livers of adult offspring; these changes are accompanied by hypomethylation in the promoter regions of these genes in both the second (F1) and third (F2) generations, suggesting that epigenetic modifications of key genes involved in postnatal metabolism may mediate some of the effects of maternal undernutrition and can be transmitted to more than one generation (Burdge et al. 2007).

There are also observational data in humans suggesting that $11 \beta$-HSD type 2 activity in pregnancy may be important. In Finland, consumption of liquorice, made from the rhizome of the plant Glycyrrhiza glabra, is high, with a significant proportion $(11 \%)$ of pregnant women consuming more than $500 \mathrm{mg}$ per week (Strandberg et al. 2001). Liquorice contains glycerrhizin which blocks activity of $11 \beta$-HSD-2. Eight-year-old offspring of women who consumed more than $500 \mathrm{mg}$ liquorice/week had elevated morning salivary cortisol concentrations and also increased cortisol responses to a Trier social stress test compared with zero to low ( $<250 \mathrm{mg} /$ week) consumers (Raikkonen et al. 2010). They also had evidence of impaired cognitive development, with lower scores on the vocabulary (word knowledge and verbal fluency), similarities (abstract reasoning, categories, relationships), and block design (spatial, visual abstract problem solving) subscales of the Wechsler Intelligence Scale for Children III (Raikkonen et al. 2009). Narrative memory scores were also lower, and children exhibited higher scores for externalizing behavior. However, women who were high consumers also had a significantly higher risk for preterm birth (odds ratio for preterm birth prior to 34 weeks' gestation compared with zero-low consumers 3.07 (95\% confidence intervals 1.17-8.05) (Strandberg et al. 2001)). As it is becoming increasingly clear that even late preterm birth (beyond 33 weeks' gestation) is associated with impaired neurodevelopmental outcomes (see below), it is difficult to be certain that the outcomes described in these studies are indeed due to exposure of the fetus to excess maternal glucocorticoids. 
There are also limited data on the effect of chronic undernutrition on circulating maternal glucocorticoid concentrations in mammals with longer gestational periods. The best data come from studies in sheep which have a gestation length of 145-150 days and a fetal developmental profile which is not dissimilar to that of the human. Large mammals are also outbred, in contrast to the inbred, genetically highly similar, strains of rodents. This results in increased variability in the data, but also means that results are likely to apply widely across the species. When ewes were chronically undernourished from 60 days before mating to 30 days after, there was an initial up-regulation of the maternal HPAA in response to onset of undernutrition, but this was then followed by a chronic down-regulation which persisted for 20 days beyond the end of the period of undernutrition (Jaquiery et al. 2006). The down-regulation of the maternal HPAA was accompanied by decreased activity of placental $11 \beta$-HSD-2; however, activity remained lower in the undernourished ewes in midpregnancy after maternal HPAA activity had returned to normal (Connor et al. 2009). Thus, although the period of undernutrition was accompanied by suppressed HPAA activity and decreased placental $11 \beta-H S D-2$ activity, it is possible that the fetus could have been exposed to increased maternal glucocorticoid concentrations in mid-pregnancy, 50 days after the end of undernutrition.

Thus, the effects of maternal undernutrition on fetal development may be mediated by exposure of the fetus to excessive concentrations of maternal glucocorticoids in some situations, but this may not be a unifying mechanism in all cases.

\section{Maternal nutrition in early pregnancy, preterm birth, and epigenetic changes in the fetus}

Although many of the animal studies investigating maternal nutrition have applied the nutritional insult during gestation, maternal nutritional status in the pre-pregnancy and early pregnancy periods is attracting increasing attention. Maternal moderate undernutrition in sheep, extending from 2 months before pregnancy until placental attachment is complete, results in preterm birth (Bloomfield et al. 2003). Fetal developmental trajectory is also perturbed, with late gestation fetuses of periconceptionally undernourished ewes demonstrating accelerated maturation of the HPAA and the glucose-insulin axis (Oliver et al. 2001; Bloomfield et al. 2004). These fetuses also have hypomethylation and hyperacetylation (H3K9) of the GR and proopiomelanocortin genes in the ventral hypothalamus (Stevens et al. 2010). This region plays a critical role in regulating appetite and satiety, and 5-year-old offspring of periconceptionally undernourished ewes have increased fat mass as a propor- tion of total body mass (Oliver, Jaquiery, Harding, and Bloomfield, unpublished data). Thus, maternal nutrition in the early pregnancy period, when fetal nutrition is histiotrophic rather than hemotrophic (Bloomfield and Harding 2006), results in epigenetic changes in regions of the brain that do not even mature until a stage of gestation that is beyond the period of undernutrition. These epigenetic changes in appetite regulatory centers are associated with altered adult fat mass. Adult offspring also demonstrate altered laterality (Hernandez et al. 2007), akin to handedness in humans, increased aversion to humans (Hernandez et al. 2007), and suppressed HPAA responses to a stress test (Hernandez et al. 2010; Oliver et al. in press), but no differences in learning ability in a maze test (Hernandez et al. 2007), compared with offspring of ewes that were well nourished throughout pregnancy.

Undernutrition in early pregnancy is also associated with an increased risk of preterm birth in humans. Women in the Gambia who conceive during the rainy season, a time of year when the average weight loss due to sparse food supply is $2.6 \mathrm{~kg}$ or $5 \%$ of body weight, equating to a daily energy deficit of $10-15 \%$, have significantly shorter gestation lengths than those who conceive during the harvest season (Rayco-Solon et al. 2005a). Women with the lowest body weight at the time of conception were most at risk (Rayco-Solon et al. 2005b). Once again, there are intriguing data suggesting that altered maternal nutrition around the time of conception is associated with epigenetic change in the offspring. In the Gambian studies, methylation of five genes which display a stochastic regulation of methylation in the normal population (termed metastable epialleles) was increased by approximately $10 \%$ compared with children conceived during the dry season (Waterland et al. 2010). Metastable epialleles in genetically identical mice are associated with pronounced phenotypic variability (Morgan et al. 1999), including a propensity to obesity. If the same is true in humans, then identification of epigenetic marks in early life may provide a means both of identifying individuals at risk and of targeting potential interventions.

These data are supported by data from the longitudinal studies of adults conceived during the Dutch Hunger Winter at the end of the Second World War. Sixty-yearold offspring of women who were exposed to famine in the periconceptional period had decreased methylation of the IGF2 differentially methylated region compared with samesex non-exposed siblings (Heijmans et al. 2008). Methylation of other genes, notably the INSIGF locus of the IGF-2 gene (derived from the INS gene and alternatively spliced to downstream IGF2 exons), was specific both for sex and for the exposure window (periconceptional vs late gestational exposure to famine) (Tobi et al. 2009). These sex and exposure window-specific effects for methylation of specific genes match the sex and exposure window specificity 
of various phenotypic traits, including psychiatric and metabolic outcomes (Susser et al. 1996; Lumey et al. 2009; Ravelli et al. 1999), following in utero exposure to the Dutch famine.

Following on from these experimental and observational studies, recent data from two prospective cohort studies of women in the south of England suggest that early life identification of epigenetic marks which may identify individuals at risk of a later adverse phenotype may indeed be possible (Godfrey et al. 2011). The Southampton Women's survey prospectively followed 12,579 nonpregnant women, a proportion of whom became pregnant (Inskip et al. 2006). Umbilical cord DNA was collected at birth, and body composition measured by DXA scan at age 6 years, in 239 children born to these women. The Princess Anne cohort followed women who were less than 17 weeks' pregnant and collected dietary information via a food frequency questionnaire at 15 weeks' gestation. Seventyeight of the babies born to women in this cohort had both DNA from umbilical cord collected at birth and body composition measured at age 9 years. In both of these cohorts, promoter methylation of retinoid X-receptor $\alpha$ (RXRA) in umbilical cord tissue was associated with fat mass and \% fat mass in children at age 6 (Southampton Women's survey cohort) and 9 (Princess Anne cohort) years (Godfrey et al. 2011). RXRA is a nuclear receptor involved in transcriptional regulation of a variety of genes including the peroxisome proliferator-activated receptors, which are known to be involved in insulin sensitivity, adipogenesis, and fat metabolism. In the Princess Anne cohort, maternal nutritional data were available at 15 weeks' gestation; mothers with the lowest carbohydrate intake in early pregnancy $(<261.5 \mathrm{~g} /$ day $)$ had children with the highest promoter methylation of RXRA, further indicating an association between maternal nutrition, offspring metabolic phenotype, and epigenetic regulation.

\section{Twin conception per se is associated with altered fetal development and epigenetic marks}

Status as a twin is, of course, determined early after conception. If the concept that events very early in pregnancy may determine both pregnancy outcome and postnatal phenotype, then the study of twin pregnancies may provide valuable insights. Twin conceptions have increased dramatically over the past three to four decades (Chauhan et al. 2010; Pinborg 2005), partly as a consequence of increasing use of assisted reproductive technology and partly secondary to increasing maternal age. Twins are born both earlier and smaller than singletons, even when only spontaneous births are considered (Chauhan et al. 2010). Observational studies in humans suggest that fetal reduction of higher order multiples to twins or to singletons may not completely abrogate the increased risk of preterm birth and reduced birthweight associated with multiple pregnancies (Wimalasundera 2010). Pregnancies in sheep also may be either singleton or twin. We have exploited this fact to test the impact of twin conception on gestation length and size at birth experimentally. Random fetal reduction of one twin of a pair in early pregnancy, with the remaining fetus continuing pregnancy as a singleton after having been conceived a twin, does not prevent the shorter gestation length and reduced size at birth seen in twin pregnancies which underwent a sham procedure and in which both fetuses continued to term (Digby et al. 2009). That is, gestation length and size at birth in twins are largely determined in early pregnancy. Although the association between twin conception and later risk of adult disease has been controversial (Phillips et al. 2001), more recent data utilizing within twin-pair statistical techniques suggest that, indeed, twins are at increased risk of diabetes and altered fat deposition in later life (Poulsen et al. 2009; Vaag and Poulsen 2007). A comparison between twins and singletons in the Avon Longitudinal Study of Parents and Children found that language development at age 20 months in twins was approximately 1.7 months behind that of singletons (MacArthur Communicative Development Inventory, by questionnaire), increasing to 3.1 months at 3 years of age (McCarthy Scales of Children's Abilities, administered by researchers) (Rutter et al. 2003). Twins had lower scores on all subscales of the Preschool Language Scales 3-verbal score, perceptual score, quantitative score, and general cognitive index. The authors concluded that these differences were not due to earlier birth, developmental immaturity, or family factors but were related to status as a twin (Rutter et al. 2003). Within twin pairs there is frequently discordance for language development, with the heritability estimated at between 0.35 and 1.0 (Stromswold 2001). In monozygotic twin pairs, heritability for language development is estimated to be about 0.6 (Stromswold 2001), and antenatal and perinatal environmental factors appear to play a larger role in discordant language development in twins than do postnatal factors (Stromswold 2006). Evidence that monozygotic twins within a twin pair have different levels of gene expression in two different cell types (umbilical vein endothelial cells and blood mononuclear cells) at birth (Gordon et al. 2011) suggests that antenatal environmental factors, in addition to stochastic effects, may alter gene expression in utero, presumably via epigenetic mechanisms. The findings that $19 \%$ of monozygotic twins differ with respect to the $\mathrm{X}$ chromosome inactivated (Wong et al. 2010; Wong et al. 2011), and that epigenetic differences in twins increase with increasing age (Wong et al. 2010; Fraga et al. 2005) provides further evidence that phenotypic differences 
within twin pairs are epigenetically determined and that this can occur before birth (Bell and Spector 2011). The differences in $\mathrm{X}$ chromosome inactivation patterns suggest that epigenetic differences in twins are likely to occur as early as the wave of epigenetic reprogramming in early embryonic life; however, differences in $\mathrm{X}$ chromosome inactivation at this time are likely to be stochastic. Preliminary data from studies in sheep, demonstrating different epigenetic responses to periconceptional undernutrition between singletons and twins (Begum et al. 2011) suggest that environmentally driven epigenetic modifications in early pregnancy may also explain some of the differences in outcomes between singleton and twin pregnancies.

\section{Late preterm birth}

As can be seen from the above, both periconceptional undernutrition and twin conception result in altered fetal development and earlier birth. Although gestation length may be reduced, in the majority of cases birth still occurs either in the late preterm period or within the range defined as term (Papageorghiou et al. 2008). The incidence of preterm birth overall has increased significantly over the past few decades, and the majority of the increase is in late preterm gestations (Raju 2006). Only some of the increase can be explained by increasing maternal age, increasing use of assisted reproductive technologies and consequently increased numbers of multiple conceptions. Recent data suggest that even in developed countries, maternal nutritional status is suboptimal in many women of child-bearing age (Inskip et al. 2009; Jacobs-Starkey et al. 2001; McDermott et al. 2009). Dieting (Johnstone et al. 2005; Johnstone et al. 2008), and both low and high extremes of body mass index (Han et al. 2011), are associated with an increased risk for preterm birth and may also affect fetal development (Poston et al. 2011; Haugen et al. 2005). It is not known whether some of the increase in late preterm births may be due to maternal nutritional status. However, it is now clear that late preterm birth is itself associated with long-term effects on health and neurodevelopment. Birth between 35 and 36 completed weeks' gestation is associated with increased use of antihypertensive medications in young adulthood (Crump et al. 2011) and both blood pressure and insulin sensitivity are inversely related to gestational age across the late preterm birth and early term range of gestations (Dalziel et al. 2007). Late preterm birth is also associated with lower scores on reading scales, increased need for individualized educational programs and increased enrolment in special education in the first years at school (Chyi et al. 2008). Both intelligence quotient and requirement for special education are inversely related to gestational age at birth (MacKay et al. 2010; Kerr-Wilson et al. 2011) and, for requirement for special education, this inverse relationship extends across the range of normal term gestations up to 41 weeks' gestation (MacKay et al. 2010). Within IQ subtests, school age children born at late preterm gestations, but who do not have special educational needs, have lower scores for ideation, sustained attention and hyperactivity, and higher scores for internalizing problems (van Baar et al. 2009). There are very few data on the development of language in late preterm babies. One small study used questionnaire responses from teachers, general practitioners, and parents to identify behavior and learning problems in all late preterm births in the county of Oxfordshire in 1990 (Huddy et al. 2001). Teacher responses were only obtained for $66 \%(n=117)$. These responses suggested that children born at late preterm gestations had incidences of speaking/listening and reading difficulties that were significantly higher than population averages. However, the potential difficulties with these data must be acknowledged; more robust studies of the consequences of late preterm birth on language and cognitive development and on behavior are urgently needed.

Babies born preterm can also be thought of as undergoing a nutritional challenge, as postnatal growth faltering following preterm birth is common (Fenton 2003; Cole et al. 2011). Although a discussion of the literature on postnatal nutrition and neurodevelopmental outcome following preterm birth is beyond the scope of this paper, the relationship between head circumference, growth, estimated brain volume, and neurodevelopment is well established (Bartholomeusz et al. 2002; Yeung 2006). A potential link between prenatal growth, postnatal growth, nutrition, and cognitive development may be through nutritional regulation of the mammalian target of rapamycin (mTOR) pathway. mTOR complex 1 has been described as a cellular nutrient sensor, receiving signals from nutrients, particularly amino acids, and hormones such as insulin and insulinlike growth factor 1 (Kim 2009). Activation of mTOR results in phosphorylation of downstream effector proteins and the promotion of cell growth and proliferation. The recent recognition that various neurodevelopmental disorders, including some with endophenotypes in the speech and language domain such as autistic spectrum disorder and tuberous sclerosis complex, can be linked with the overactivation of the mTOR pathway with effects on synaptic connectivity thus provide a potential link between nutrition in the developing organism and the basis of disorders of cognitive development (Kelleher and Bear 2008; de Vries 2010). It is not yet known whether this link may be mediated through epigenetic regulation of the mTOR signalling pathway, as has been shown to occur through the Evil leukemia oncogene in myeloid malignancies (Yoshimi and Kurokawa 2011). 


\section{Conclusion}

Maternal periconceptional undernutrition, twin conception, and late preterm birth are all associated with altered development and increased risks for adverse neurodevelopmental and metabolic outcomes in childhood and later life. Maternal periconceptional undernutrition and twin conception also both are associated with an increased risk of late preterm birth. It is not known whether some of the late preterm births without obvious cause may have their origin in early pregnancy events. Maternal nutritional factors and twin conception also are associated with epigenetic change in the offspring; there are no data on whether late preterm birth is associated with epigenetic changes. Thus, it is possible that epigenetic changes in response to environmental signals may represent a unifying mechanism explaining the long-term consequences of a poor start to life and these changes may occur very early in pregnancy. The challenge will be to determine whether interventions can prevent, or modify, these effects, thereby resulting in a healthier start to life and optimizing both later metabolic and neurodevelopmental outcomes.

Acknowledgments I would like to acknowledge the contributions of Professors Jane Harding and John Challis, and Drs. Oliver, Jaquiery, and Hancock, to the concepts outlined in this paper, the Health Research Council of New Zealand and the National Research Centre for Growth and Development for funding of research carried out by this laboratory and referred to in this paper, and the Merrill Center for Advanced Studies for the opportunity to share this work with colleagues in a highly stimulating environment.

Conflict of interest statement The author does not have any conflicts of interest to declare.

\section{References}

Bartholomeusz HH, Courchesne E, Karns CM. Relationship between head circumference and brain volume in healthy normal toddlers, children, and adults [Research Support, U.S. Gov't, P.H.S.]. Neuropediatrics. 2002;33(5):239-41.

Begum G, Connor KL, Challis JRG, Bloomfield FH, White A. Epigenetic changes in the pro-opiomelanocortin (POMC) gene in hypothalamic feeding centres in singleton and twin sheep fetuses as a result of maternal nutritional programming. Endocr Rev. 2011;32(3):P3-P234.

Bell JT, Spector TD. A twin approach to unraveling epigenetics. Trends Genet. 2011;27(3):116-25.

Blondeau B, Lesage J, Czernichow P, Dupouy JP, Breant B. Glucocorticoids impair fetal beta-cell development in rats. Am J Physiol Endocrinol Metab. 2001;281(3):E592-9.

Bloomfield FH. How is maternal nutrition related to preterm birth? Annu Rev Nutr. 2011;31:235-61.

Bloomfield FH, Harding JE. Fetal nutrition. In: Hay Jr WW, Thureen PJ, editors. Neonatal nutrition and metabolism. Cambridge: Cambridge University Press; 2006. p. 1-22.
Bloomfield FH, Oliver MH, Hawkins P, Campbell M, Phillips DJ, Gluckman PD, et al. A periconceptional nutritional origin for noninfectious preterm birth. Science. 2003;300(5619):606.

Bloomfield FH, Oliver MH, Hawkins P, Holloway AC, Campbell M, Gluckman PD, et al. Periconceptional undernutrition in sheep accelerates maturation of the fetal hypothalamic-pituitary-adrenal axis in late gestation. Endocrinology. 2004;145(9):4278-85.

Burdge GC, Lillycrop KA. Nutrition, epigenetics, and developmental plasticity: implications for understanding human disease. Annu Rev Nutr. 2010;30:315-39.

Burdge GC, Slater-Jefferies J, Torrens C, Phillips ES, Hanson MA, Lillycrop KA. Dietary protein restriction of pregnant rats in the F0 generation induces altered methylation of hepatic gene promoters in the adult male offspring in the F1 and F2 generations. Br J Nutr. 2007;97(3):435-9.

Chauhan SP, Scardo JA, Hayes E, Abuhamad AZ, Berghella V. Twins: prevalence, problems, and preterm births. Am J Obstet Gynecol. 2010;203(4):305-15.

Chyi LJ, Lee HC, Hintz SR, Gould JB, Sutcliffe TL. School outcomes of late preterm infants: special needs and challenges for infants born at 32 to 36 weeks gestation. J Pediatr. 2008; 153(1):25-31.

Cole TJ, Statnikov Y, Santhakumaran S, Pan H, Modi N. Postnatal weight gain after very preterm birth: a population study. Arch Dis Child. 2011;96 Suppl 1:A3-4.

Connor KL, Challis JR, van Zijl P, Rumball CW, Alix S, Jaquiery AL, et al. Do alterations in placental 11 beta-hydroxysteroid dehydrogenase (11betaHSD) activities explain differences in fetal hypothalamic-pituitary-adrenal (HPA) function following periconceptional undernutrition or twinning in sheep? Reprod Sci. 2009;16(12):1201-12.

Crump C, Winkleby MA, Sundquist K, Sundquist J. Risk of hypertension among young adults who were born preterm: a Swedish national study of 636,000 births. Am J Epidemiol. 2011;173(7):797-803.

Dalziel SR, Parag V, Rodgers A, Harding JE. Cardiovascular risk factors at age 30 following pre-term birth. Int $\mathrm{J}$ Epidemiol. 2007;36(4):907-15.

de Vries PJ. Targeted treatments for cognitive and neurodevelopmental disorders in tuberous sclerosis complex [Research Support, Non-U.S. Gov't Review]. Neurotherapeutics. 2010;7(3):275-82.

Digby SN, Oliver MH, Bloomfield FH. Twin conception reduces birth weight and gestation length in sheep, regardless of fetal number in late gestation. J Dev Orig Health Dis. 2009;1(S1):S8.

Feng S, Jacobsen SE, Reik W. Epigenetic reprogramming in plant and animal development. Science. 2010;330(6004):622-7.

Fenton TR. A new growth chart for preterm babies: Babson and Benda's chart updated with recent data and a new format. BMC Pediatr. 2003;3:13.

Fowden AL, Forhead AJ. Hormones as epigenetic signals in developmental programming. Exp Physiol. 2009;94(6):607-25.

Fowden AL, Li J, Forhead AJ. Glucocorticoids and the preparation for life after birth: are there long-term consequences of the life insurance? Proc Nutr Soc. 1998;57:113-22.

Fraga MF, Ballestar E, Paz MF, Ropero S, Setien F, Ballestar ML, et al. Epigenetic differences arise during the lifetime of monozygotic twins. Proc Natl Acad Sci U S A. 2005;102 (30):10604-9.

Gillman MW. Epidemiological challenges in studying the fetal origins of adult chronic disease. Int J Epidemiol. 2002;31(2):294-9.

Godfrey KM, Sheppard A, Gluckman PD, Lillycrop KA, Burdge GC, McLean C, et al. Epigenetic gene promoter methylation at birth is associated with child's later adiposity. Diabetes. 2011;60 (5):1528-34.

Gordon L, Joo JH, Andronikos R, Ollikainen M, Wallace EM, Umstad $\mathrm{MP}$, et al. Clues to the effect of intrauterine milieu on gene 
expression from a study of two tissues from neonatal monozygotic twins. Epigenetics. 2011;6(5):579-92.

Han Z, Mulla S, Beyene J, Liao G, McDonald SD. Maternal underweight and the risk of preterm birth and low birth weight: a systematic review and meta-analyses. Int J Epidemiol. 2011;40 (1):65-101

Harding JE, Derraik JGB, Bloomfield FH. Maternal undernutrition and endocrine development. Expert Rev Endocrinol Metab. 2010;5(2):297-312.

Haugen G, Hanson M, Kiserud T, Crozier S, Inskip H, Godfrey KM. Fetal liver-sparing cardiovascular adaptations linked to mother's slimness and diet. Circ Res. 2005;96(1):12-4.

Heijmans BT, Tobi EW, Stein AD, Putter H, Blauw GJ, Susser ES, et al. Persistent epigenetic differences associated with prenatal exposure to famine in humans. Proc Natl Acad Sci U S A. 2008;105(44):17046-9.

Heinonen K, Raikkonen K, Pesonen AK, Kajantie E, Andersson S, Eriksson JG, et al. Prenatal and postnatal growth and cognitive abilities at 56 months of age: a longitudinal study of infants born at term. Pediatrics. 2008;121(5):e1325-33.

Heinonen K, Raikkonen K, Pesonen AK, Andersson S, Kajantie E, Eriksson JG, et al. Behavioural symptoms of attention deficit/ hyperactivity disorder in preterm and term children born small and appropriate for gestational age: a longitudinal study. BMC Pediatr. 2010;10:91.

Hernandez CE, Oliver MH, Bloomfield FH, Held S, Harding JE, Matthews LR. Periconceptional undernutrition in sheep increases aversion to humans and modifies laterality in the offspring. 41st International Congress of the International Society for Applied Ethology, Merida, Mexico, ISAE 2007 2007:83.

Hernandez CE, Matthews LR, Oliver MH, Bloomfield FH, Harding JE. Effects of sex, litter size and periconceptional ewe nutrition on offspring behavioural and physiological response to isolation. Physiol Behav. 2010;101(5):588-94.

Huddy CL, Johnson A, Hope PL. Educational and behavioural problems in babies of $32-35$ weeks gestation. Arch Dis Child Fetal Neonatal Ed. 2001;85(1):F23-8.

Inskip HM, Godfrey KM, Robinson SM, Law CM, Barker DJ, Cooper C. Cohort profile: The Southampton Women's Survey [Research Support, N.I.H., Extramural Research Support, Non-U.S. Gov't]. Int J Epidemiol. 2006;35(1):42-8.

Inskip HM, Crozier SR, Godfrey KM, Borland SE, Cooper C, Robinson SM. Women's compliance with nutrition and lifestyle recommendations before pregnancy: general population cohort study. BMJ. 2009;338:b481.

Jacobs-Starkey L, Johnson-Down L, Gray-Donald K. Food habits of Canadians: comparison of intakes of adults and adolescents to Canada's Food Guide to Healthy Eating. Can J Diet Pract Res. 2001;62(2):61-9.

Jaquiery AL, Oliver MH, Bloomfield FH, Connor KL, Challis JRG, Harding JE. Fetal exposure to excess glucocorticoid is unlikely to explain the effects of periconceptional undernutrition in sheep. $\mathrm{J}$ Physiol. 2006;572(Pt 1):109-18.

Johnstone J, Godfrey K, Challis JRG. Effect of maternal preconception body composition and diet on placental enzyme activity and gestation length. Pediatr Res. 2005;58:1032 (abstract O-086).

Johnstone JF, Inskip H, Crozier S, Lewis RM, Hanson M, Challis JRG, et al. Relationships between maternal body composition prior to conception and duration of gestation. Reprod Sci. 2008;15(2):225A.

Jones A, Godfrey KM, Wood P, Osmond C, Goulden P, Phillips DI. Fetal growth and the adrenocortical response to psychological stress. J Clin Endocrinol Metab. 2006;91(5):1868-71.

Kajantie E, Feldt K, Raikkonen K, Phillips DI, Osmond C, Heinonen K, et al. Body size at birth predicts hypothalamic-pituitary-adrenal axis response to psychosocial stress at age 60 to 70 years. The Journal of Clinical Endocrinology and Metabolism. 2007;92(11):4094-100.
Kelleher 3rd RJ, Bear MF. The autistic neuron: troubled translation? Cell. 2008;135(3):401-6.

Kerr-Wilson CO, Mackay DF, Smith GC, Pell JP. Meta-analysis of the association between preterm delivery and intelligence. J Public Health (Oxf). 2011. doi:10.1093/pubmed/fdr024.

Kim E. Mechanisms of amino acid sensing in mTOR signaling pathway. Nutr Res Pract. 2009;3(1):64-71.

Langley-Evans SC. Maternal carbenoxolone treatment lowers birthweight and induces hypertension in the offspring of rats fed a protein-replete diet. Clin Sci (Lond). 1997;93(5):423-9.

Langley-Evans SC, McMullen S. Developmental origins of adult disease. Med Princ Pract. 2010;19(2):87-98.

Lesage J, Bondeau B, Grino M, Breant B, Dupouy JP. Maternal undernutrition during late gestation induces fetal overexposure to glucocorticoids and intrauterine growth retardation, and disturbs the hypothalamo-pituitary-adrenal axis in the newborn rat. Endocrinology. 2001;142:1692-702.

Liggins GC. The role of cortisol in preparing the fetus for birth Reprod Fertil Dev. 1994;6(2):141-50.

Lumey LH, Stein AD, Kahn HS, Romijn JA. Lipid profiles in middleaged men and women after famine exposure during gestation: the Dutch Hunger Winter Families Study. Am J Clin Nutr. 2009;89 (6): 1737-43

MacKay DF, Smith GC, Dobbie R, Pell JP. Gestational age at delivery and special educational need: retrospective cohort study of 407,503 schoolchildren. PLoS Med. 2010;7(6):e1000289.

McDermott R, Campbell S, Li M, McCulloch B. The health and nutrition of young indigenous women in north Queenslandintergenerational implications of poor food quality, obesity, diabetes, tobacco smoking and alcohol use. Public Health Nutr. 2009;12(11):2143-9.

McMillen IC, Robinson JS. Developmental origins of the metabolic syndrome: prediction, plasticity, and programming. Physiol Rev. 2005;85(2):571-633.

Morgan HD, Sutherland HG, Martin DI, Whitelaw E. Epigenetic inheritance at the agouti locus in the mouse. Nat Genet. 1999;23 (3):314-8.

Muhlhausler BS, Hancock SN, Bloomfield FH, Harding R. Are Twins Growth Restricted? Pediatr Res. 2011; doi:10.1203/ PDR.0b013e31821f6cfd.

Nobili V, Alisi A, Panera N, Agostoni C. Low birth weight and catchup-growth associated with metabolic syndrome: a ten year systematic review. Pediatr Endocrinol Rev. 2008;6(2):241-7.

Oliver MH, Hawkins P, Breier BH, Van Zijl PL, Sargison SA, Harding JE. Maternal undernutrition during the periconceptual period increases plasma taurine levels and insulin response to glucose but not arginine in the late gestational fetal sheep. Endocrinology. 2001;142(10):4576-9.

Oliver MH, Bloomfield FH, Jaquiery AL, Todd SE, Thorstensen EB, Harding JE. Periconceptional undernutrition suppresses cortisol response to arginine vasopressin and corticotrophin releasing hormone challenge in adult sheep offspring. J Dev Origins Health Dis. In Press.

Papageorghiou AT, Bakoulas V, Sebire NJ, Nicolaides KH. Intrauterine growth in multiple pregnancies in relation to fetal number, chorionicity and gestational age. Ultrasound Obstet Gynecol. 2008;32(7):890-3.

Phillips DI, Walker BR, Reynolds RM, Flanagan DE, Wood PJ, Osmond $\mathrm{C}$, et al. Low birth weight predicts elevated plasma cortisol concentrations in adults from 3 populations. Hypertension. 2000;35(6):1301-6.

Phillips DI, Davies MJ, Robinson JS. Fetal growth and the fetal origins hypothesis in twins-problems and perspectives. Twin Res Official J Intl Soc Twin Stud. 2001;4(5):327-31.

Pinborg A. IVF/ICSI twin pregnancies: risks and prevention. Hum Reprod Update. 2005;11(6):575-93. 
Poston L, Harthoorn LF, Van Der Beek EM. Obesity in pregnancy: implications for the mother and lifelong health of the child. A consensus statement. Pediatr Res. 2011;69 (2): $175-80$.

Poulsen P, Grunnet LG, Pilgaard K, Storgaard H, Alibegovic A, Sonne $\mathrm{MP}$, et al. Increased risk of type 2 diabetes in elderly twins. Diabetes. 2009;58(6):1350-5.

Raikkonen K, Pesonen AK. Early life origins of psychological development and mental health. Scand J Psychol. 2009;50 (6):583-91.

Raikkonen K, Pesonen AK, Heinonen K, Lahti J, Komsi N, Eriksson $\mathrm{JG}$, et al. Maternal licorice consumption and detrimental cognitive and psychiatric outcomes in children. Am J Epidemiol. 2009; 170(9):1137-46.

Raikkonen K, Seckl JR, Heinonen K, Pyhala R, Feldt K, Jones A, et al. Maternal prenatal licorice consumption alters hypothalamicpituitary-adrenocortical axis function in children. Psychoneuroendocrinology. 2010;35(10):1587-93.

Raju TN. Epidemiology of late preterm (near-term) births. Clin Perinatol. 2006;33(4):751-63. abstract vii.

Ravelli AC, van Der Meulen JH, Osmond C, Barker DJ, Bleker OP. Obesity at the age of $50 \mathrm{y}$ in men and women exposed to famine prenatally. Am J Clin Nutr. 1999;70(5):811-6.

Rayco-Solon P, Fulford AJ, Prentice AM. Differential effects of seasonality on preterm birth and intrauterine growth restriction in rural Africans. Am J Clin Nutr. 2005a;81(1):134-9.

Rayco-Solon P, Fulford AJ, Prentice AM. Maternal preconceptional weight and gestational length. Am J Obstet Gynecol. 2005b;192 (4):1133-6.

Reik W. Stability and flexibility of epigenetic gene regulation in mammalian development. Nature. 2007;447(7143):425-32.

Reik W, Walter J. Genomic imprinting: parental influence on the genome. Nat Rev Genet. 2001;2:21-32.

Reynolds RM, Godfrey KM, Barker M, Osmond C, Phillips DI. Stress responsiveness in adult life: influence of mother's diet in late pregnancy. J Clin Endocrinol Metab. 2007;92(6):2208-10.

Roberts D, Dalziel S. Antenatal corticosteroids for accelerating fetal lung maturation for women at risk of preterm birth. Cochrane database of systematic reviews (Online). 2006; Issue 3:Art. No.: CD004454. doi:10.1002/14651858.CD004454.pub2.

Rutter M, Thorpe K, Greenwood R, Northstone K, Golding J. Twins as a natural experiment to study the causes of mild language delay: I: Design; twin-singleton differences in language, and obstetric risks. J Child Psychol Psychiatry. 2003;44(3):326-41.

Seckl JR, Meaney MJ. Glucocorticoid programming. Ann N Y Acad Sci. 2004;1032:63-84.
Stevens A, Begum G, Cook A, Connor K, Rumball C, Oliver M, et al. Epigenetic changes in the hypothalamic proopiomelanocortin and glucocorticoid receptor genes in the ovine fetus after periconceptional undernutrition. Endocrinology. 2010;151(8):3652-64.

Strandberg TE, Jarvenpaa AL, Vanhanen H, McKeigue PM. Birth outcome in relation to licorice consumption during pregnancy. Am J Epidemiol. 2001;153(11):1085-8.

Stromswold K. The heritability of language: a review and metaanalysis of twin, adoption and linkage studies. Language. 2001;77:647-723.

Stromswold K. Why aren't identical twins linguistically identical? Genetic, prenatal and postnatal factors. Cognition. 2006;101 (2):333-84.

Susser E, Neugebauer R, Hoek HW, Brown AS, Lin S, Labovitz D, et al. Schizophrenia after prenatal famine. Further evidence. Arch Gen Psychiatry. 1996;53(1):25-31.

Tobi EW, Lumey LH, Talens RP, Kremer D, Putter H, Stein AD, et al. DNA methylation differences after exposure to prenatal famine are common and timing- and sex-specific. Hum Mol Genet. 2009;18(21):4046-53.

Vaag A, Poulsen P. Twins in metabolic and diabetes research: what do they tell us? Curr Opin Clin Nutr Metab Care. 2007;10(5):591-6.

van Baar AL, Vermaas J, Knots E, de Kleine MJ, Soons P. Functioning at school age of moderately preterm children born at 32 to 36 weeks' gestational age. Pediatrics. 2009;124(1):251-7.

Waterland RA, Jirtle RL. Early nutrition, epigenetic changes at transposons and imprinted genes, and enhanced susceptibility to adult chronic diseases. Nutrition. 2004;20(1):63-8.

Waterland RA, Kellermayer R, Laritsky E, Rayco-Solon P, Harris RA, Travisano M, et al. Season of conception in rural gambia affects DNA methylation at putative human metastable epialleles. PLoS Genet. 2010;6(12):e1001252.

Wimalasundera RC. Selective reduction and termination of multiple pregnancies. Semin Fetal Neonatal Med. 2010;15(6):327-35.

Wong CC, Caspi A, Williams B, Craig IW, Houts R, Ambler A, et al. A longitudinal study of epigenetic variation in twins. Epigenetics. 2010;5(6):516-26.

Wong CC, Caspi A, Williams B, Houts R, Craig IW, Mill J. A longitudinal twin study of skewed $\mathrm{X}$ chromosome-inactivation. PLoS One. 2011;6(3):e17873.

Yeung MY. Postnatal growth, neurodevelopment and altered adiposity after preterm birth-from a clinical nutrition perspective [Review]. Acta Paediatr. 2006;95(8):909-17.

Yoshimi A, Kurokawa M. Evil forms a bridge between the epigenetic machinery and signaling pathways. Oncotarget. 2011;2(7):575-86. 